\title{
TRANSPARENCY INFORMED CONSENT RELATED TO PATIENT DISHONESTY AMID COVID-19 PANDEMIC IN INDONESIA: IN LAW PERSPECTIVE
}

\author{
${ }^{1}$ Tiwuk Herawati, ${ }^{2 *}$ Fifik Wiryani, ${ }^{3}$ M. Nasser, ${ }^{4}$ Mokhammad Najih \\ ${ }^{1}$ Master of Law, Universitas Muhammadiyah Malang, tiwukners@gmail.com \\ ${ }^{2}$ Master of Law, Universitas Muhammadiyah Malang, fwiryani2016@gmail.com \\ ${ }^{3}$ Master of Law, Universitas Muhammadiyah Malang, nasserkelly@yahoo.com \\ ${ }^{4}$ Master of Law, Universitas Muhammadiyah Malang, najihumm17@gmail.com
}

\begin{abstract}
To break the chain of transmission of covid-19 outbreak, the public is expected to be honest in explaining chronological physical contact when treating to health facilities, especially if the patient experiences symptoms of covid-19. Honesty of patients indicated by COVID-19 is very important so that the chain of transmission of covid-19 does not expand and facilitate health workers in data collection. Denial, lies, even like the refusal of covid-19 corpses if it continues to be left, does not mean the countermeasures of covid-19 are increasingly stretched. This article tries to review the transparency of informed consent in relation to patient dishonesty, where transparent communication is expected by the patient to be honest and not to cover the perceived symptoms or various things related to covid-19. This research is normative juridical research. In normative legal research, library material is the basic data that in research science is classified as secondary data.
\end{abstract}

Keywords: Covid-19; Informed Consent; Dishonesty; Transparency

\section{Introduction}

World Health Organization (WHO) has released a report on Saturday, April 11, 2020, based on data as of Wednesday, April 8, 2020, there are approximately 22,073 health workers from 52 countries infected with Covid-19 cases. The number is much larger, considering there are no systematic reports of infection among health workers. According to the study, the health workers were infected from the workplace, the community, even many infected from their family members. Who calls for the rights of health workers to decent working conditions and to pay attention to the risk of fatigue among them. WHO also stressed the importance of using correct personal protective equipment (PPE) ranging from masks, glasses, gloves and so on ${ }^{1}$

In the United States from February 12 to April 9, 2020, it was announced that there were $9,282(19 \%$ of the 49,370$)$ health workers infected with Covid $-19^{2}$. While the number of deaths of health workers is $0.16 \%$ (27 deaths of health workers per 16,570 total deaths due to covid-19).

Levvy Larassaty, WHO: Lebih Dari 22.000 Petugas Kesehatan Di Dunia Terinfeksi Covid-19 (Grid Health, 2020).

2 Mohamamd Syahrul RA, Yusuf Hamdika, and Sholahuddin Al-Fatih, "The Impact of COVID-19 Through the Lens of Islamic Law: An Indonesian Case," Lentera Hukum 7, no. 3 (2020): 267-78, doi:https://doi.org/10.19184/ejlh.v7i3.18983. 
In the UK, one of the countries in Europe that has a high mortality rate, until May 2020 the health workers' deaths were $0.5 \%$ (165 deaths per 28,131 total deaths due to covid-19) ${ }^{3}$. In Italy, it was reported that infections among medical circles reached 10\%, Spain reported health workers infections reached $20 \%$. In Malaysia, the government has reported that $5.8 \%$ of positive cases are health workers ${ }^{4}$.

In Jakarta, the number of health workers infected with Covid-19 is 174 people as of April $2020^{5}$. Meanwhile, based on data from the Curative Team Task Force in East Java, there are 93 health workers exposed to covid-19 as of May 18, 2020 or about 5 percent of the number of confirmed positive cases of covid-19 in East Java ${ }^{6}$.

In addition to the lack of personal protective equipment (PPE), dishonesty factors of patients when asked for information also affect health workers infected with Covid-19 ${ }^{7}$. The reason Covid-19 positive patients do not provide correct information is because they are worried about getting negative stigma from the public, especially from their colleagues who have interacted with them for some time. Actually, patients with Covid-19 positive are not criminals, so there is no need to lie or hide something in order to save the lives of many people including health workers who help them avoid exposure to the virus. ${ }^{8}$

To break the chain of transmission of Covid-19 outbreak, the public is expected to be honest in explaining chronological physical contact when treating to health facilities, especially if the patient experiences symptoms of coronavirus or Covid- $19^{9}$. Honesty of patients indicated by COVID-19 is very important so that the chain of transmission of covid-19 does not expand and facilitate health workers in data collection. If the patient is dishonest then it can be entangled with article 378 of the Criminal Code on fraud. Patient honesty is also contained in article 26 letter (d) Permenkes RI Number 4 year 2018 and article 14 of law in 1984, as well as in Law

3 Sholahuddin Al-Fatih, Fachry Ahsany, and Ahmad Faiz Alamsyah, "Legal Protection of Labor Rights During the Coronavirus Disease 2019 (Covid-19) Pandemic," Jurnal Pembaharuan Hukum 7, no. 2 (2020): 100-115, doi:10.26532/jph.v7i2.10975.

4 Irwandy Irwandy, "Petugas Kesehatan Gugur Akibat Covid-19: Pentingnya Data Terbuka Dokter Dan Perawat Yang Terinfeksi Virus Corona" (The Conversation, 2020).

5 Halik Malik, "Virus Corona: Mengapa Tenaga Kesehatan Tertular Covid-19 Ditengah Komitmen Pemerintah Menyalurkan APD” (BBC News Indonesia, 2020).

6 Gugus Tugas Tim Kuratif, "Update Virus Corona Di Jatim 18 Mei 2020, Ada 93 Tenaga Kesehatan Jatim Terpapar Covid-19" (Surya.co.id, 2020).

7 Tommaso Lupia et al., "2019 Novel Coronavirus (2019-NCoV) Outbreak: A New Challenge,” Journal of Global Antimicrobial Resistance 21 (2020): 22-27, doi:10.1016/j.jgar.2020.02.021.

8 Harif Fadillah, “Tenaga Medis Jadi Korban Corona: Pasien Harus Jujur Beri Informasi,” 2020.

9 Mireya Castro-Verdes et al., "Corona Virus Disease 2019 in Situ Arterial and Venous Thrombosis in Critically Ill Patients: A Case Series,” ed. Monika Arzanauskaite et al., European Heart Journal - Case Reports, December 2020, doi:10.1093/ehjcr/ytaa470. 
Number 6 Year 2018 article 93 concerning Health Quarantine. Which reads "where everyone who does not comply with the implementation of Health Quarantine as referred to in article 9, paragraph 1, and /or obstructs the implementation of health quarantine thus causing public health emergency in prison 1 year and a fine of Rp 100 million. $^{10}$

On April 17, 2020 cases of dishonest patients have occurred at dr. Kariadi Hospital Semarang. At that time, the patient who came to the treatment did not say that he had just traveled from the red zone of Covid-19, as a result there were 46 medical personnel consisting of specialist doctors, nurses, medical support personnel to nonmedical personnel at local hospitals exposed to Covid-19 so that they had to undergo self-isolation at the Hotel for 14 Days. Previously on April 10, 2020 there was also news related to the dishonesty of patients in Purwodadi Hospital to cause 76 hospital employees to be declared positive for Covid-19. A senior nurse at Siloam Hospital Surabaya also died from covid-19 on April 16, 2020.

People are asked to be open and honest in the midst of the Covid-19 pandemic according to BNPB volunteer dr. Tirta Mandira Hudhi because now the most dangerous in efforts to handle and prevent the spread of Covid-19 is precisely the group of people without symptoms commonly referred to as OTG. They do not have any symptoms, but it turns out that they are infected with Covid-19, therefore people like this should be honest when conducting health checks. According to the Executive Board of the Indonesian Doctors Association (IDI) that no fewer than 24 doctors died from Covid-19, while according to the Chairman of the Central Board of the Indonesian National Nurses Association (PPNI) Harif Fadillah at least 16 nurses died due to Covid-19. From the data as of April 2020 no fewer than 40 health workers have died in the heavy task of handling covid-19. ${ }^{11}$

Based on the background described above, there are 2 (two) main problems that will be raised in this research, namely: 1) How is Transparency of Informed Consent of Covid-19 Patients? And 2) What are the patient consequences if they lie?

\section{Methods}

This research is normative juridical research (literature law research) ${ }^{12}$. In normative legal research ${ }^{13}$, library material is the basic data that in research science is classified as secondary

10 Makson Parulian Purba, "Tak Jujur Saat Diperiksa, Pasien Bisa Dijerat Hukuman Setahun Penjara" (Sindonews.com, 2002).

11 Redaksi WE Online, "Lagi, Pasien Tak Jujur Telan Korban: Seorang Dokter Di Surabaya Meninggal" (WE Online, 2020).

12 Peter Mahmud Marzuki, Penelitian Hukum: Edisi Revisi, Cetakan ke (Jakarta: Kencana, 2017). 
data $^{14}$. In addition, the approach taken is a conceptual approach in which the approach to communication to patients is before making an informed consent contract and after performing medical services.

\section{Results and Discussion}

\subsection{Transparency Informed Consent of Covid-19 Patients}

Approval after explanation (Informed Consent) is the consent given by the patient and his family on the basis of information and explanation of any medical actions taken against the patient. ${ }^{15}$ In fact, informed consent is a process of communication between the doctor and the patient regarding the agreement of medical actions that the doctor will take against the patient. This agreement may be oral or written. The signing of the informed consent form in writing is only a confirmation of what has been agreed before. The purpose of a complete explanation is for the patient to make his/her own decision according to the patient's own choice ${ }^{16}$.

As health workers we must be transparent to patients. Transparency in relation to human beings can not be separated from the basic rules. The principle of basic principles there are 4 namely 1) respect for autonomy (respect for autonomy of patients) is closely related to the basis of respect for human dignity with all its characteristics because he is a human being who has value and has the right to ask, 2) beneficience (do good) this principle or rule does not only require human beings to treat others as autonomous beings and not hurt them, but it is also required that the human being can judge the kindness of others furthermore, 3) Nonmaleficience (not harming others) the purpose of this principle is to protect a person who is not capable (disabled) or people who are not- autonomy, 4) justice, ends up being justice which is the same because one feels that one is not treated properly even though they have been treated the same as each other ${ }^{17}$.

Regulation on the approval of action or informed consent as stated in article 45 paragraph 2 of Law No.29/2004 on Medical Practice which states that approval is given after the patient

13 Johnny Ibrahim, Teori Dan Metodologi Penelitian Hukum Normatif (Malang: Bayumedia, 2007).

14 Irwansyah Irwansyah, Penelitian Hukum: Pilihan Metode \& Praktik Penulisan Artikel, ed. Ahsan Yunus (Yogyakarta: Mirra Buana Media, 2020).

15 Herman Warouw, "Hubungan Pengetahuan Dengan Pelaksanaan Persetujuan Setelah Penjelasan (Informed Consent) Pada Pasien Di IRDB BLU RSUP Prof Dr.R.D Kandou," Jurnal Keperawatan Poltekes Kemenkes Menado, n.d.

16 Achmad Busro, “Aspek Hukum Persetujuan Tindakan Medis ( Inform Consent ) Dalam Pelayanan Kesehatan," Law \&Justice Journal 1, no. 1 (2018): 1-18.

17 Dedi Afandi, “Tinjauan Pustaka Kaidah Dasar Bioetika Dalam Pengambilan Keputusan Klinis Yang Etis" 40, no. 2 (2017): 111-21, doi:10.22338/mka.v40.i2.p111-121.2017. 
gets a complete explanation $^{18}$. Article 56 of Law No. 36/2009 on Health also states that everyone has the right to accept or reject some or all of the actions that will be given to him or her after receiving and understanding the information about the act in full ${ }^{19}$. In article 37 letter e of Law No. 38/2014 on Nursing states that nurses provide complete, honest, correct, clear and understandable information about nursing actions to patients. ${ }^{20}$

The special rules governing the approval of medical measures have been contained in PMK No. 290/2008 article 7 which states that an explanation of medical action must be given directly to the patient and or next of kin, whether requested or not requested. ${ }^{21}$ From the above regulations, it means that you must inform or explain in advance not just ask for the signature of the patient and his family. Approval of action on confirmed Covid-19 patients using the same legal basis and does not need to be distinguished from non-Covid-19 patients which includes the patient's diagnosis, objectives, alternatives, risks and complications, prognosis, and estimated cost.

It is also contained in article 5 of Decree No.4/2018 concerning hospital obligations and patient obligations stating that information relating to medical services to patients includes: providing services, diagnosis and procedures of medical measures, objectives of medical measures, alternative measures, risks and complications that may occur, rehabilitative and prognosis of actions carried out until the estimated financing. That we as health workers to explain persuasively and transparently to patients about covid-19 disease so that patients are also transparent and patients do not lie to health workers when identification is carried out. As stated in article 26, the obligation of the patient is to provide honest, complete and accurate information in accordance with his/her ability and knowledge of his health problems, providing information about his financial ability and health insurance. There are sanctions for hospitals that do not carry out their obligations, but there are no sanctions for patients who do not carry out their obligations. $^{22}$

\subsection{The Patient Consequences if They Lie}

The spread of Covid-19 in Indonesia is increasingly widespread and the number of positive cases is increasing. The government encourages everyone to stay at home amid the spread of

\footnotetext{
18 “Undang- Undang Republik Indonesia Nomor 29 Tahun 2004 Tentang Praktik Kedokteran” (2004).

19 Undang Undang Nomor 36 Tahun 2009 Tentang Kesehatan, 2009.

20 Undang Undang Nomor 38 Tahun 2014 Tentang Keperawatan, 2014.

21 PMK No. 290 Th 2008 Ttg Persetujuan Tindakan Kedokteran, n.d.

22 Peraturan Menteri Nomor 4 Tahun 2018 Tentang Kewajiban Rumah Sakit Dan Kewajiban Pasien, 2018.
} 
coronavirus. This is done to reduce the number of victims infected with Covid-19 in Indonesia. The main thing that is handling the corona outbreak is honest patient information whether it comes from the red zone and other related problems. Honesty is considered important in combating the Covid-19 pandemic. It is also very dangerous for health workers who are on duty because they have to face the patient directly. In fact, the honesty of the patients will be very helpful and accelerate the treatment and save themselves and the lives of many people. ${ }^{23}$

Covid-19 disease caused by coronavirus type SARS-COV-2 is becoming a scourge for many people. Uncooperative public behavior exacerbates the identification of Covid-19 patients. After spending three money with the patient, the family often lied and waisted to the medic when questioned about his travel history. Not only lying, the patient's family is also angry with the officer when questioned about his travel history and contact list over the last few days.. The main factor of patients covering their history, because some people who consider corona as a disgrace so that it must be excommunicated. This is a form of anxiety from someone facing the covid-19 pandemic. $^{24}$

This is closely related to the lack of literacy regarding health, where people are not accustomed to dealing with balanced data. The ability to balance positive and negative information and the lack of health literacy give rise to so-called stigma. The stigma that arises in this case is that Covid-19 positive patients will be shunned, isolated, away from their families. Whether the patient will fully recover, or will infect the person closest to him. What happens next is the reverse behavior of help seeking, where patients should seek help to a health facility. Rejection from society is a sign of this stigma emerging in a very quick time. Denial, lies, even like the rejection of covid-19 corpses. If these denials and lies are constantly allowed, it does not mean that the response to Covid-19 in Indonesia will be more stretched. Targeted communication and counseling and balanced information in accordance with economic class and social status. ${ }^{25}$

Effective communication between health workers and patients is one of the most important competencies and must be mastered by health workers. Communication competence determines success in helping to solve patient health problems. Effective communication based on transparency, honesty and understanding, patients also tell the pain and complaints honestly and

23 Vidia Elfa Safhira, "Pasien Bohong Buat 46 Tenaga Medis RS Kariadi Positif COVID-19” (PikiranRakyatcom, 2020).

24 Fidiansyah Fidiansyah, "Dokter Jiwa Jelaskan Mengapa Pasien Corona Bohong Soal Riwayat, Singgung Masyarakat Yang Anggap Aib" (Tribunews.com, 2020).

25 Sri Anindiati Nursastri, "Mengapa Pasien Covid-19 Kerap Menyangkal Dan Berbohong” (Kompas.com, 2020). 
clearly. Patients feel safe and protected, reduce patient doubts, and increase patient compliance. Based on various literatures on the laws of effective communication namely REACH: Respect, Humble (laceheart), Empathy (putting yourself in situations faced by others), Audible (listenable), Clarity (clarity) ${ }^{26}$.

In therapeutic transactions there are several underlying legal principles including the principle of legality, the principle of balance, the principle of timely, the principle of good faith, the principle of caution, the principle of honesty and the principle of openness. In the midst of the covid-19 pandemic, identifying patients using the principle of honesty and openness from the implementation of good information delivery by patients and health workers in communicating and honesty in conveying information is very helpful in-patient recovery. Good communication is expected to be honest and does not cover the symptoms felt or various things related to covid19. Good communication is like how to show empathy to the patient, with good communication the patient is sure to accept. The truth of this information is closely related to the right of every human being to know the truth. Medical services that are effective and successful in order to be achieved if there is openness and good cooperation between health workers and patients based on mutual trust. This attitude can grow if there is therapeutic communication between health workers and patients where the patient obtains explanations or information from health workers in this transparent communication ${ }^{27}$. In addition, the obligation to establish communication is also stated in Law No. 29 of 2004 concerning Medical Practice, article 45 concerning approval of medical actions, which in taking actions against patients must obtain verbal or written approval.

There are many underlying factors that patients tell dishonestly in getting health care. Unpreparedness and lack of socialization to the public that this covid-19 disease causes disgrace or stigma that is not true, thereby causing anxiety and encouraging patients to be dishonest. There are also health facilities that are afraid to treat covid-19 patients due to APD limitations and unclear financing of covid-19 patients. Educational factors that consider covid-19 disease underestimated, and sociocultural factors of the Indonesian nation that cultivate physical contact such as shaking hands that can cause spread and some patients do not understand about the way covid-19 transmission. Many in the encounter banners or banners containing threats to dishonest patients or lying patients can be subject to articles 202, 205, 351, 352, 355 Criminal Code.

26 Endang Fourianalistyawati, "Komunikasi Yang Relevan Dan Efektif Antara Dokter Dan Pasien,” Journal Psikogenesis 1, no. 1 (2012): 82-87.

27 Busro, “Aspek Hukum Persetujuan Tindakan Medis ( Inform Consent ) Dalam Pelayanan Kesehatan.” 
Porigin- the article cannot be used as a legal basis in the dishonesty of patients during the covid19 pandemic because in the criminal article there is no multi-interpretation.

In Law No.4/1984 on Infectious Disease Outbreak in article 14 states that anyone who deliberately obstructs the implementation of the outbreak is threatened with imprisonment for a maximum of 1 (one) year and or a fine as high as one million rupiah. ${ }^{28}$ Examples in article 14 are rejecting the bodies of covid-19 patients, as well as violations of PSBB (large-scale social restrictions). The limitations in this Law are less clear so that whether patients lie or are dishonest can be subject to this sanction as in some hospitals that have made banners "be honest to us or be jailed". This kind of communication makes the patient threatened, it would be better with a more persuasive sentence and there is no need for threats to patients who are already stressed, it is better to invite the public more humanist and replace the sentence of threat with better sentences.

\section{Conclusions}

The use of humanist and persuasive sentences is more aware of the community and gives rise to beliefs such as: "Your Honesty Saves You and Us", "Your Honesty Is Our Main Capital", "You As a Hero If You Are Honest", Your Honesty Saves Our Lives" so that patients feel comfortable not threatened, therefore it takes persuasive communication by paying attention to religion, customs, habits, education level, social, economic and community development in order for patients to provide honest and transparent communication. Transparency will be realized if there is trust and communication. Because a lack of transparency will lead to less distrust and insecurity. Humanist elements, ethical elements, must remain in the eye. More aware to the public that covid-19 is not a disease of disgrace and the transmission is clear, it becomes a shared responsibility. Therapeutic communication is carried out at all stages from pre-contract therapy to completion of medical service actions.

\section{Acknowledgement}

Our greatest thank to University of Muhammadiyah Malang which gave us fully funded research grants, so we can publish this article in the best way. We also thanks to the Editor of this journal, who accept our research. May God bless us.

28 Undang Undang Nomor 4 Tahun 1984 Tentang Wabah Penyakit Menular, 1984. 


\section{References}

Afandi, Dedi. “Tinjauan Pustaka Kaidah Dasar Bioetika Dalam Pengambilan Keputusan Klinis Yang Etis" 40, no. 2 (2017): 111-21. doi:10.22338/mka.v40.i2.p111-121.2017.

Al-Fatih, Sholahuddin, Fachry Ahsany, and Ahmad Faiz Alamsyah. "Legal Protection of Labor Rights During the Coronavirus Disease 2019 (Covid-19) Pandemic.” Jurnal Pembaharuan Hukum 7, no. 2 (2020): 100-115. doi:10.26532/jph.v7i2.10975.

Busro, Achmad. "Aspek Hukum Persetujuan Tindakan Medis ( Inform Consent ) Dalam Pelayanan Kesehatan.” Law \&Justice Journal 1, no. 1 (2018): 1-18.

Castro-Verdes, Mireya, Antonia Gkouma, John Wort, Carole Ridge, Saeed Mirsadraee, Simon Padley, Awais Sheikh, and Suveer Singh. "Corona Virus Disease 2019 in Situ Arterial and Venous Thrombosis in Critically Ill Patients: A Case Series." Edited by Monika Arzanauskaite, Kyriakos Dimitriadis, Christoph Jensen, Kajaluxy Ananthan, and Ross Thomson. European Heart Journal - Case Reports, December 2020. doi:10.1093/ehjcr/ytaa470.

Fadillah, Harif. “Tenaga Medis Jadi Korban Corona: Pasien Harus Jujur Beri Informasi,” 2020.

Fidiansyah, Fidiansyah. "Dokter Jiwa Jelaskan Mengapa Pasien Corona Bohong Soal Riwayat, Singgung Masyarakat Yang Anggap Aib.” Tribunews.com, 2020.

Fourianalistyawati, Endang. "Komunikasi Yang Relevan Dan Efektif Antara Dokter Dan Pasien." Journal Psikogenesis 1, no. 1 (2012): 82-87.

Ibrahim, Johnny. Teori Dan Metodologi Penelitian Hukum Normatif. Malang: Bayumedia, 2007.

Irwandy, Irwandy. "Petugas Kesehatan Gugur Akibat Covid-19: Pentingnya Data Terbuka Dokter Dan Perawat Yang Terinfeksi Virus Corona." The Conversation, 2020.

Irwansyah, Irwansyah. Penelitian Hukum: Pilihan Metode \& Praktik Penulisan Artikel. Edited by Ahsan Yunus. Yogyakarta: Mirra Buana Media, 2020.

Kuratif, Gugus Tugas Tim. "Update Virus Corona Di Jatim 18 Mei 2020, Ada 93 Tenaga Kesehatan Jatim Terpapar Covid-19.” Surya.co.id, 2020.

Larassaty, Levvy. WHO: Lebih Dari 22.000 Petugas Kesehatan Di Dunia Terinfeksi Covid-19. Grid Health, 2020.

Lupia, Tommaso, Silvia Scabini, Simone Mornese Pinna, Giovanni Di Perri, Francesco Giuseppe De Rosa, and Silvia Corcione. "2019 Novel Coronavirus (2019-NCoV) Outbreak: A New Challenge." Journal of Global Antimicrobial Resistance 21 (2020): 22-27. doi:10.1016/j.jgar.2020.02.021. 
Transparency Informed Consent Related to Patient Dishonesty Amid Covid-19 Pandemic in Indonesia: In Law Perspective

Malik, Halik. "Virus Corona: Mengapa Tenaga Kesehatan Tertular Covid-19 Ditengah Komitmen Pemerintah Menyalurkan APD.” BBC News Indonesia, 2020.

Marzuki, Peter Mahmud. Penelitian Hukum: Edisi Revisi. Cetakan ke. Jakarta: Kencana, 2017.

Nursastri, Sri Anindiati. "Mengapa Pasien Covid-19 Kerap Menyangkal Dan Berbohong." Kompas.com, 2020.

Peraturan Menteri Nomor 4 Tahun 2018 Tentang Kewajiban Rumah Sakit Dan Kewajiban Pasien, 2018.

PMK No. 290 Th 2008 Ttg Persetujuan Tindakan Kedokteran, n.d.

Purba, Makson Parulian. "Tak Jujur Saat Diperiksa, Pasien Bisa Dijerat Hukuman Setahun Penjara." Sindonews.com, 2002.

RA, Mohamamd Syahrul, Yusuf Hamdika, and Sholahuddin Al-Fatih. "The Impact of COVID19 Through the Lens of Islamic Law: An Indonesian Case." Lentera Hukum 7, no. 3 (2020): 267-78. doi:https://doi.org/10.19184/ejlh.v7i3.18983.

Redaksi WE Online. "Lagi, Pasien Tak Jujur Telan Korban: Seorang Dokter Di Surabaya Meninggal.” WE Online, 2020.

Safhira, Vidia Elfa. "Pasien Bohong Buat 46 Tenaga Medis RS Kariadi Positif COVID-19." PikiranRakyatcom, 2020.

Undang- Undang Republik Indonesia Nomor 29 Tahun 2004 Tentang Praktik Kedokteran (2004).

Undang Undang Nomor 36 Tahun 2009 Tentang Kesehatan, 2009.

Undang Undang Nomor 38 Tahun 2014 Tentang Keperawatan, 2014.

Undang Undang Nomor 4 Tahun 1984 Tentang Wabah Penyakit Menular, 1984.

Warouw, Herman. "Hubungan Pengetahuan Dengan Pelaksanaan Persetujuan Setelah Penjelasan (Informed Consent) Pada Pasien Di IRDB BLU RSUP Prof Dr.R.D Kandou.” Jurnal Keperawatan Poltekes Kemenkes Menado, n.d. 